\title{
Microcystic/Reticular Schwannoma
}

National Cancer Institute

\section{Source}

National Cancer Institute. Microcystic/Reticular Schwannoma. NCI Thesaurus. Code C5321.

The rarest histopathologic subtype of Schwannoma. The reported cases have been located in the gastrointestinal submucosa or subcutaneous tissue. Morphologically it is characterized by the presence of a microcyst-rich network of spindle cells with minimal amount of cytoplasm and Antoni A tissue. 